\title{
Is the United States Juvenile Justice System Working: An Empirical Investigation from the Life Course
}

\author{
Approach \\ Robert Knox, MPA \\ Texas Southern University \\ Email: po_officer@yahoo.com,robert.knox@hcjpd.hctx.net \\ Don Anthony Woods, PhD \\ Texas Southern University \\ G. Solomon Osho, $\mathrm{PhD}$ (Corresponding author) \\ Prairie View A\&M University, Member of the Texas A\&M University System \\ Email: gsosho@pvamu.edu
}

Received: January 07, 2013 Accepted: March 05, 2013 DOI: 10.5296/jpag.v3i1.3006

\begin{abstract}
The juvenile court was given jurisdiction over neglect and dependent children for the purpose of this act the words dependent child and neglected shall mean any child who for any reason is destitute or homeless, abandoned, no proper parental care or guardianship; or who habitually begs or receives alms; or who is found living, in any house of ill fame or with any vicious or disreputable person; or whose home, by reason of neglect, cruelty or depravity on the part of its parents, guardian or other person in whose care it may be, is an unfit place for such a child" (Abadinsky pg 102). In 1968 Congress "passed the Juvenile Delinquency Prevention and Control Act. The act was designed to encourage states to develop plans and programs that would work on community levels to discourage juvenile delinquency. The Juvenile Delinquency Prevention and Control Act was precursor to the extensive Juvenile Justice and Delinquency Prevention Act that replaced it in 1974. However, to prevent a juvenile from committing a crime or re-offending, this study believes that the juvenile court and the state legislators must designed a program that juveniles can participate in and engage them in positive activities. This way a youth will change his or her behavior and become a law-abiding citizen.
\end{abstract}

Keywords: Juvenile Court, Juvenile Delinquency Prevention, Detention Home, Probation 


\section{Introduction}

The first Juvenile Court was established in 1899 in Chicago, Illinois as a byproduct of the Progressive Era. "The Illinois Juvenile Court Law of 1899 represented a departure from earlier methods of dealing with dependent and delinquent children, not just in Chicago but in the whole United States. It not only marked the final recognition by the State of Illinois of its duty towards children, but symbolized a new attitude towards young people in justice system, seeing them as children in need of help rather than as criminals to be punished". Before the court was established, anyone that committed a crime between the age of thirteen and seventeen was placed in the same system as the adults. "But, children under the age of twelve were never held responsible for their criminal acts. The law considered them incapable of forming the necessary criminal intent". Although early reformers that were helping with rehabilitating juveniles rather then seeing them placed with adults, build a New York House of Refuge in 1824. It was a reformatory that housed juveniles that would have been placed in an adult jail. By 1899, other states took notice of the problems they were having with young offenders and began establishing similar home such as New York. "The juvenile court was given jurisdiction over neglect and dependent children for the purpose of this act the words dependent child and neglected shall mean any child who for any reason is destitute or homeless, abandoned, no proper parental care or guardianship; or who habitually begs or receives alms; or who is found living, in any house of ill fame or with any vicious or disreputable person; or whose home, by reason of neglect, cruelty or depravity on the part of its parents, guardian or other person in whose care it may be, is an unfit place for such a child" (Abadinsky pg 102).

The main focus of the juvenile court in 1899 was, providing help to rehabilitate young offenders and looking out for the best interest of the child. More importantly rehabilitation was more important than punishment. Most children were redeemable, and lawmakers believe that judges making individualized decisions about children could best determine whether the juvenile court was the appropriate forum to prosecute a case, then the adult system. During that time, the juvenile court system varied from state to state. In 1899 the juvenile court was founded with high expectations and goals on helping children in the justice system. The system was supposed to help and rehabilitate a child. In practice the justice system sometimes failed to rehabilitate. Also, it "denied young people the protection and rights guaranteed by adults. In many cases, juveniles were processed through a system with few safeguards and little hope for treatment. However, in 1966, the Supreme Court began to change began to change the theory and operation of the juvenile justice system and one of the questions that was debated and still is; "should teenagers have the same rights as adult under the Constitution? Several cases have dealt with this question and the answer is not always yes. In some instances the court has stated "that in certain situations teenagers can be treated differently".

In 1966, there was a Supreme Court case dealing with the rights of a teenager, In Gault Minor. Gerald Francis Gault was a boy living in Arizona and he was on probation for, being with a friend that stole a wallet from a woman's purse. The juvenile court ordered Gault to six months probation. "On June 8, 1964, while Gault was still on probation a neighbor named 
Mrs. Cook complained to the police that Gault had a friend made an obscene telephone call to her. Police arrested Gault while his parents were at work and took him to the Children Detention Home. When Gault's mother arrived home, she had to search to find her in the detention home. Superintendent Flagg told Mrs. Gault that there would be a hearing the next day in juvenile court.

The juvenile court held two hearings for Gualt's case, the police never told Gault what law he was accused of breaking. They did not explain that he could have an attorney represent him in court. The court did not even require Mrs. Cook to testify against Gault. Instead, it relied on testimony by Superintendent Flagg that Gault admitted to making an obscene telephone call to Cook. According to Judge McGhee, Gault even confessed during the second hearing to making the obscene comments on the telephone. Gault's parents denied this, saying that Gault only denied. Cook number and then handed the telephone to his friend.

Based on the testimony, Judge McGhee decided that Gault was a juvenile delinquent and ordered Gault to be confined in the State Industrial School, a juvenile detention center, until he was twenty-one. Gault was only fifteen at the time, so he faced six years in detention. If Gault had been an adult, his crime would have been punishable by only two months". Gault's parents did not think that the state should be allowed to adjudicate their son for six years for making an obscene phone, without giving him the same rights as criminal defendants. The Gault's filed a lawsuit against the State of Arizona for holding their son in detention without giving him a fair trial. However, the Arizona Superior Court dismissed the case, but the Arizona Supreme Court affirmed the case. The Gaults then appealed to the United States Supreme Court. The U.S. Supreme Court ruled in favor of the Gault's by an 8-1 vote which led to the Gault son being released from detention. Supreme Court Judge Abe Fortas stated, "Neither the Fourteenth Amendment nor the Bill of Rights is for adults only. Even though a juvenile case is not a criminal case, sending a juvenile to a detention center takes away his liberty and freedom".

Also, Judge McGhee stated "that Gault's constitutional rights had been violated and that Gault was entitled to: 7 adequate notice of the precise nature of the charges brought against him notice of the right to counsel and if indigent, the right to have counsel appointed. The right to confront witnesses and have them cross-examined. The privilege against self-incrimination, which applies to juvenile and adult proceedings when the court concluded that, because the non-criminal label attached to juvenile proceedings, did not dictate the scoop of the juvenile's rights, calling such matter "civil" would not dictate the parameter of the rights prescribed. Gault marked the constitutional domestication of the parens patriae juvenile court, and a new era dawned based on a more criminal due process model contrasted with the historic informality of the juvenile court proceedings. The Gault decision affected the way all juveniles are treated in court today". After this Supreme Court Case, Congress passed two acts that would help with the problem with juvenile delinquency. In 1968 Congress "passed the Juvenile Delinquency Prevention and Control Act. The act was designed to encourage states to develop plans and programs that would work on community levels to discourage juvenile delinquency. He programs, once drafted and approved, would receive federal funding. The Juvenile Delinquency Prevention and Control Act was precursor 
to the extensive Juvenile Justice and Delinquency Prevention Act that replaced it in 1974.

\section{Review of Literatures}

By 1974 the United States had develop a strong momentum towards preventing juvenile delinquency, deinstitutionalizing youth already in the system, and keeping juvenile offenders separate from adults offenders. The Juvenile Justice and Delinquency Prevention Act of 1974 created the following entities: The Office Juvenile Justice and Delinquency Prevention (OJJDP),

The Runaway Youth Program and the National Institute for Juvenile Justice and Delinquency Prevention (NIJJDP), in order to receive funds made by the act, states were required to remove youth from secured detention centers and correctional facilities and separate juvenile delinquents from convicted adults". Part of the rational behind the separation from the adult court and jail was to keep juvenile offenders from learning worse behaviors from the older inmates.

Some cities have more then one Juvenile Court. For instance, Houston, Texas has three Juvenile Courts, the $313^{\text {th }}, 314^{\text {th }}$ and $315^{\text {th }}$ District Courts. Each court has limited jurisdiction and the legal age for a Juvenile start at 10 years old and ends at 16 years old. "The system used for juveniles in the United States is based on a philosophy radically different from the one on which the adult criminal justice system rest". The adult system philosophy is to rehabilitate and punish a person for his or her crime and release them from jail or prison as a law-abiding citizen. However, critics have stated that, the juvenile court lacks sufficient punishment for juvenile offenders. According to

John Braithewaite and Stephen Mugford, Professors at Australian National University stated, "The Juvenile System is failing because it lacks adequate resources and articulates a vision of success. If the juvenile justice system is under-funded, it is also under-conceptualized". "Explaining crime and delinquency is a complex task. A multitude of factors exists that contribute to the understanding of what leads someone to engage in delinquent behavior. While biological and psychological factors hold there own merit when explaining crime and delinquency, perhaps social factors can best explain juvenile delinquency". Some people believe that punishment is the answer to change a juvenile behavior. However, punishment can be use inappropriately resulting in a negative effect on rehabilitating the offender.

"Ironically, retributive punishment may encourage offenders to focus on themselves rather than on their victims. Even increasing its severity may have little impact if we have miscalculated the extent to which sanctions such as incarceration are experienced as punishment". The juvenile court system on punishment is at least somewhat related to the offense. Treatment that the offender receives only treats part of the juvenile needs. Sometimes counseling programs have sessions with five to ten clients at a time. Often the counselor will ask little of the client beyond participation in the group. While the real problems that the offender is having gone unresolved. In the mind of the public such programs may or may not work, "they make little difference in the lives of the victim of juvenile crime, citizens concerned with the safety of their neighborhoods, or individuals who want young offenders 
held accountable for their actions".

Is juvenile justice system really rehabilitating juvenile offenders or by treating the offenders with counseling workshop and community interaction programs. Judge Cindy S. Lederman of the $11^{\text {th }}$ Judicial Circuit Court in Florida, states the Juvenile Justice court system is a noble institution, its under-funded, often unappreciated institution charged with the most important duty imaginable, protecting and reforming our children when all else has failed". In the past few years the juvenile justice system has changed and the courts are starting to enforce stiffer punishment for juvenile offenders and less therapeutic methods. "There have been significant changes in the State juvenile codes based not on data or research, but on the misconception that America is in the midst of a violent juvenile crime epidemic" 4. In 1997 out of 105,790 youths detained in juvenile facilities prior to adjudication or committed to state juvenile correctional centers, minority youths represented $63 \%$ even though they only represented $34 \%$ the total population in the United States at that time. However, White youths represented $71 \%$ of the youth arrested for crimes committed across the nation. But, only $37 \%$ of White youths are detained.

In 1997-98, Africa American youth represented $15 \%$ of the total youth population, but $26 \%$ of the youth arrested, $31 \%$ of the youth were referred to juvenile court and $44 \%$ of the youth were detained. During the 90 s 30 out 50 states contained $83 \%$ of the US population minority youths represented the majority of the youths in detention. A Police presents and "coercive force has become an acceptable substitute, even a preferred substitute, for ways to resolve conflicts and satisfy needs for the public when dealing juvenile crime. Most of the research in this area revolves around neighborhood factors, such as the presence of gangs, illicit drug networks, high levels of transiency, lack of informal support". "It is generally accepted that intense public concern about the threat of youth crime has driven this trend, and the public supports legislation inclination toward increased punitiveness". It's not clear whether this view of the public's attitude about the appropriate response to juvenile crime is accurate. "However, various opinion surveys have found public support generally for getting tougher on juvenile crime and punishing youths as harshly as their adult counterparts". There are some policy makers who have doubts that, the public supports adult punishment of juveniles is based largely on responses to highly publicized crimes such as school shooting or on mass opinion polls that typically ask a few simplistic questions". Also, policy makers often justify expenditures for punitive juvenile justice reforms on the basis of popular demand for tougher policies.

Punitive responses to juvenile crime are far more expensive than less harsh alternative. Further, "there is little evidence that more punitive policies are effective in deterring future criminal activity and some evidence that overly punitive responses, such as the incarceration of juvenile offenders in adult facilities, actually may increase juvenile offending". If politicians' misread public sentiment it could led to the adoption of more expensive policy alternative than the public actually wants, tax dollars would be wasted on policies that are costly and possibly ineffective. Also, may be less popular than is widely assumed". "Popular explanations of juvenile crimes often rest on ideals about the corrupting influence of television, movies music videos, video games, rap/hip hop music, or the latest scapegoat $d u$ 
jour, computer games Doom or Quake. The fact is that TV is much more pervasive and has become the de facto babysitter in many homes, with little or no parental monitoring. The nation's children watch an astonishing 19,000 hours of TV by the time they finish high school much more time than all their classroom hours put together since the first grade. By, eighteen, they will have seen 200,000 acts of violence, including 40,000 murders. Every hour of prime time television carries 6-8 acts of violence, when TV becomes the sole source of moral norms and values, this can cause a problem for a child". Most scientific studies in the area of children watching large amounts of TV are based on two hypotheses, the catharsis and brutalization studies. It appears that the catharsis study believes, by watching violence on TV may contribute a person to commit a violate act, but, may only be a small part on why the act was committed. Some people who watch television have become use to the violence acts that they see on TV and at the movies.

Sometimes a youth believes that he or she can perform the things that are seen in the movies. We believe that society have become desensitized to the violence that is shown on television and the movies. Public supports do not hesitate to ask questions of researches, Judges Prosecutors, Law Enforcement Officers, juveniles' advocates, and others involved with young offenders think about the relative value of juvenile and criminal sanctions. We rarely ask how the respective sanction affected those who experience the sanctions think. Most people or juvenile offenders have no ideal about the different sanctions and how they are viewed policy makers and court official. Also, when sanctions are implemented how will it affect an offenders behavior?

Some juvenile offenders that have are adjudicated and placed on probation are taking advantage of the programs offered to them. Most offenders attend Individual and Family counseling, Angry Management, Peer Pressure, Gang and weapons workshop. The juveniles and their family members will have counseling session with a highly trained counselor, free of charge. The parents and the juvenile can talk about family issues and problems that they are having at home. Policy makers and judge's consider these programs a valuable tool. "Some public supporters believe that the juvenile should be asked what he or she thinks about the adjudication ordered for him or her to serve". It not surprising, juvenile offenders are unworthy and not deserving of the right be asked about their sanctions. "Due to the offenders violating social norms, broken trust and threaten the communities". "Rates of re-offending among juvenile offenders are cause for concern for those involved in criminal justice agencies around the world. "In North America, for example, the recidivism rate for young people leaving custody has been reported to be as high as 96 per cent. In another study, 88 percent of British males between 14 and 16 re-offended within two years of release from custody". However, juvenile offenders that are following their court / community orders, appears to make the percentages be much lower. But, majority still re-offends or violates there probation. In Australia, a Victorian governmental study into recidivism among juvenile justice clients report nearly half (41\%) of a sample of more than 1,500 juvenile justice clients re-offended, with this rate rising to 61 per cent for those who had previously been on supervised orders".

Most juveniles that are on supervised probation try to comply with the rules of probation, and 
most realize if they commit another offense, he or she could be placed out of their home. Hence, the juvenile court system, sometimes have compassion and mercy on juveniles because of their age. "By this reasoning the juvenile court relies on maximizing effective rehabilitation programs for juvenile offenders". "A system review using meta-analytic techniques was conducted with 14 studies selected to provide the best evidence on the effectiveness of cognitive-behavioral programs for reducing the re-offense recidivism of criminal offenders". The results indicated that over all cognitive - behavioral programs are effective and the best of them are capable of producing sizable reductions in recidivism.

Policy-makers believe the programs that were created for juveniles, will help an offender change his delinquent behavior and become a productive citizen in the community. But, research shows that there are not enough programs in the juvenile system to service the population at hand. One of the notable characteristics of chronic offenders is distorted cognition - self justificatory thinking, misinterpretation of social cues, deficient moral reasoning, schemas of dominance and entitlement. Cognitive behavior treatments for offenders are designed to correct these dysfunctional and criminogenic thinking patterns. Counselor employ systematic training regimens training regimens aimed at creating cognitive restructuring and flexible cognitive skills such that offenders develop more adaptive patterns of reasoning and reacting in situations that trigger their criminal behavior".

For instance, counselors teach juvenile offenders how to handle stressful situations and make the right decisions when friends try to influence them to use drugs or commit a crime. The juvenile will be able to process what he or she has learned and makes the right choice. "An effective juvenile justice system that meets the twin goals of public safety and providing youth with opportunities to have a crime free life will minimize the inappropriate pre-trail detention of youth. Juveniles with serious delinquency histories or young people who been arrested for violent crimes need to be detained to keep the community safe. However, the vast majority of the youth in a detention center are awaiting trial for non-violent acts".

Most of the juveniles that are in detention have committed minor offenses and they are associating with juveniles that have committed harsher crimes. For example, the starting age that a youth can be placed in detention is 10 years old, that ten-year-old offender could be placed on the same unit with older offenders by placing minor offenders with harsher offenders. They could be exposed to information and learn how to commit other crimes. "The number of youth held in secure detention nationwide increase by 72\% from 1985 to 1995 . During this period, the proportion of detention populations made up of white youth dropped and minority youth came to represent a majority of the young people detained. Between 1983 and 1997 , the overall youth detention population increased by $47 \%$, but the detained white youth population only increased by $21 \%$, while the detained minority youth population grew by $76.2 \%$. This means that $80 \%$ of the increase in youth being detained during these years were minority or put another way, 4 out 5 new youth detained during this 15 -year period were youth of color".

The overrepresentation of minorities, particularly African Americans, in the nation's juvenile justice has received much attention in recent years. The disproportionate representation of 
racial ethnic groups is not limited to adult prison and juvenile detention centers. Unfortunately, research in the area of confinement on Latino youth is scant. "Inconsistencies in the collection and presentation of information on Latino populations in the justice system continue to be a problem, since many data system failed to desegregate ethnicity from race, Latino youth are often counted as white". Public attention is usually focused on the disproportionate number of minorities in confinement, overrepresentation of minority occurs in the early stages in the juvenile justice system. Such as to make an arrest or to detain a juvenile offender in detention pending an investigation, the decision to refer a juvenile to court, the prosecutor accepting the case and the judicial decision and subsequent sanction.

Public opinion on the overrepresentation of minorities is simple; most believe that minorities are committing more crimes then white youths. But, is this statement true or are police policies and practices causing the problem. Research has shown that police have target areas that they patrol. "Targeting patrols in certain low-income neighborhoods, police requiring immediate release to biological parents, group arrest procedures. Location of offenses, minority youth using or selling drugs on street corners, white youth using or selling drugs in the homes, different behavior by minority youth".

As we approach the next millennium the juvenile justice system is at a crossroads. The juvenile system must make a choice on the direction that will determine the future of our youth. According to Gordon Bazemore and Susan Day, providing information on the restoration of the juvenile justice system, "they have a plan as an alternative community oriented system that involved citizen in setting clear limits on antisocial behavior and establishing appropriate consequences for juvenile offenders. The balanced and restorative model is a promising new approach to the juvenile justice that focused on meaningful community involvement as an alternative to the treatment verses punishment paradigm. The problem of crime can no longer be simplified to the problem of the criminal".

Bazemore and Day believe that confining a juvenile will not correct his or he behavior, but re-enforce their behavior. Bazemore and Day new system would help intensive, community based aftercare initiative help public and private correctional agencies transition high-risk juvenile offenders from secure confinement to the community. It appears that the two researchers believe that a juvenile offender will do better in the community with supervision and counseling than confinement. But, public opinion believes that the juvenile justice system is soft on juveniles already.

"The United States law enforcement agencies made an estimated 2.6 million arrests of juveniles in 1998. Less then 5\% of those arrested were for Violate Crimes Index offenses and less than one tenth of $1 \%$ were for murder. The majority (71\%) of those arrests involved white youth. However, African American youth over represented in most offense categories. Some have argued that the over representation of minority youth in the justice system is a result of minority youth committing more crimes then white youth. Over representation is the result of "differential police policies and practices; location of offenses; different behavior by minority youth; differential reactions of victims to offenses committed by White and minority youth and racial bias within the justice system". There has been a growing national concern 
about the over population in juvenile detention centers in the United States, especially with minority youth, such as Native, African, Latino Americans.

Research has shown that minority youth; are detained in detention centers in larger numbers then to their representation in the general population. The Juvenile Justice and Delinquency Prevention Act defines the Disproportion minority "refers to a situation in which minority proportion of juveniles detained or confined in secure detention facilities, secure correctional facilities, jails and lockups exceeds the proportion of such groups in the general population”.

It appears that minority detainment is up do to police patrolling, high populated minorities' neighborhood. The overrepresentation of minorities can be contributed to the way that juveniles are processed in the system. Most of the minority youth are processed for minor offenses and placed on probation instead of being referred to deferred prosecution or creative sanctions, which will not show up as a record for a juvenile offender in future. An effective juvenile system that meets public safety and providing a crime free environment for juveniles will minimize juveniles appearing in court and being detained. This will help authorities with juveniles that are arrested for committing serious crimes, have a shorter wait to appear in court and be detained to keep the community safe. "Since the increase in juvenile detention utilization was fueled almost wholly by the increased incarceration of minority youth, any strategy designed to reduced the number of young people detained must address race, and the race effect of minorities as they travel through the justice system".

\section{Conclusion}

Juvenile crime has increased over the past few years and the offenders are committing crimes at a younger age. The Juvenile Justice System must focus on deterring youths from crimes. Most of the juvenile courts are detaining more minorities and lower income children, then Anglo America juveniles. Plus, a lot of the counseling programs designed to help juvenile offenders have been cancelled due to lack of funding or state legislators believes that the programs are no longer needed. However, to prevent a juvenile from committing a crime or re-offending, this study believes that the juvenile court and the state legislators must designed a program that juveniles can participate in and engage them in positive activities. This way a youth will change his or her behavior and become a law-abiding citizen.

We believe that the juvenile justice system must focus on correcting the behavior of the juvenile offender. Lawmakers that are more concern with public opinion to punish all juvenile offenders should consider methods for rehabilitation and be slower to advocate punitive reform in response to public presser. "Legislature enacted in this climate institutionalizes public fears that are likely short lived and may result in laws that do not reflect stable public preferences about youth crime policy”.

\section{Research Implications and Recommendations}

Lawmaker faces intense public press to change the laws concerning juveniles committing crimes. Society today believes that juveniles should be locked away like the adult counterpart until they learn how to function like a law-abiding citizen. For example, there are several television shows that bring problem children on and the parents are crying, stating that their 
child is out of control and they want the host too help them with their son or daughter. Most of the hosts send the child to boot camp for a day or make them spend a couple of hours behind bars with an inmate.

Sometimes using a scared straight tactic works and the child stays out of trouble. However, other needs intense counseling to help with their problems. Sometimes juvenile will commit a crime or causes problems in the house to get attention from his parents. Most of the juvenile that are committing crimes state that they did it because, lack of supervision at home or there were a lot of abuse problems in the home. Here, the court can really help a juvenile offender with his or her problems. When the juvenile offender appears in court, the Judge could order several weeks of counseling for the juvenile and his or her parent can work out any family problems that they are having. By, selecting intense counseling as an alternative instead of confining a juvenile, this will save tax-payers money. The high cost of placing a juvenile offender in detention has become a consideration in public opinion.

"Longer sentences translate into more prison space, more staff and generally higher operating costs. In the past few years, many states have reduced criminal sentences in recognition of the high cost of incarceration. Cost-conscious legislatures may become disenchanted with punitive juvenile justice policing economic grounds and pursue policies that place greater emphasis on rehabilitation and early childhood prevent".

\section{Reference}

[1]. Welch, C. Branch and Farrington, P. David (2001, November 1) Towards an Evidence-Based Approach to Preventing Crime: Annals of the American Academy of Political and Social Science, 2001, 578 (November).

[2]. Bureau of Justice Statistics [BJS] Source Book, 2003; Soler, 2001; Moore, 1994

[3].Lane, Jodi, Frazier, Charles and Bishop, M. Donna, Adults versus Juvenile Sanctions: Voices of Incarcerated Youths Crime \& Delinquency, Vol. 48 No. 3, July 2002431 to 455

[4].Howard Abadinsky, Probation and Parole Theory and Practice eight edition, pg 102

[5]. Mark W. Lipsey, Gagrielle L. Chapman \& Nana A. Landenberger Cognitive Behavioral Programs for Offenders, Annals of the American Academy of Political and Social Science, 2001, 578 (November).

[6].Day, Andrew, Howells, Kevin and Rickwood, Debra (2004, October) Trends and issues in crime and criminal justice, Current trends in the rehabilitation of juvenile offenders. [WWW. Document] URL

[7].http://www.aicgov.au/publications/tandi2/tandi284t.html

[8]. Building Blocks for Youth: And Justice for Some. [WWW. Document] URL

[9].http://www.buildingblocksforyouth.org/justiceforsome/jfs.html1 
[10].O'Connor, Tom (2002, December 2) Juvenile Offenders and Trouble Teens: [WWW. Document] URL http://www.faculty.ncwc.edu/toconnor/juvjusp.htm

[11].Amrosia, T., and Schiraldi, V. (1997) From Classrooms to Cellblocks: A National Perspective. Washington D.C. http://www.justicepolicy.org/article.php?\&id=40

[12]. Duxbury, Neil, (2008) Golden Rule Reasoning, Moral Judgement and Law. [WWW. Document]

[13].URL http://www.law.bepress.com/uvalwps/olin/art London School of Economics.

[14].Bazemore, Gordan and Day E. Susan, (1996, December 1) Restoring the Balance: Juvenile and Community Justice [WWW. Document]. URL http://www.ncjr.gov/txtfiles/jjjd96.txt, http://www.ncjr/htmlojidp/jijournal1299/3.html II

[15].Wikimedia Foundation, Inc: American Justice System. [WWW. Document] URL http://en.wilkipedia.org/wiki/American_juvenile_justice_system

[16].Roberts, H. Cynthia (2000, February 5) Juvenile Delinquency: Cause and Effects. http://www.yale.edu/ynhti/curriculum/units/2000/2/00.02.05.x.htmlYale-New Haven.

[17].Supreme Court of the United States, Paul Gault and Marjorie Gault, Parents of Gerald Francis Gault, a minor vs. the State of Arizona, 387 U.S. 1 (1967) Washington D.C. http://www.allsupremecourtcases.com/re-gault

[18]. History of America's Juvenile Justice System. (2000) [WWW. Documents] URL http://www.lawyershop.com/practice-areas/criminal-law/juvenile-law/history 